\title{
ESCOLHAS ESCOLARES E MODALIDADES DE SUCESSO NO ENSINO SECUNDÁRIO Percursos e temporalidades
}

\author{
Maria Manuel Vieira \\ Instituto de Ciências Sociais da Universidade de Lisboa, Lisboa, Portugal \\ Lia Pappámikail \\ Escola Superior de Educação do Instituto Politécnico de Santarém, Santarém, Portugal \\ Cátia Nunes \\ Instituto Nacional de Estatística, Lisboa, Portugal
}

\section{Introdução}

O mundo escolar encontra-se frequentemente associado a binarismos conceptuais, muitas vezes redutores. Tal é o caso da parelha de conceitos sucesso/insucesso escolar, estritamente associada ao cumprimento de requisitos institucionais de desempenho académico e comportamental. Esta abordagem é, a nosso ver, limitada, pois impede de captar outras dimensões que subjazem ao processo de construção da trajetória escolar enquanto elemento cada vez mais central da construção biográfica.

Com efeito, nas sociedades contemporâneas, as biografias, os seus tempos e transições (Pais e Ferreira, 2010) têm cada vez mais como referentes estruturadores os espaços institucionalizados em que decorre o curso de vida (Beck, 1992 [1986]). Por isso, a individuação ${ }^{1}$ dos sujeitos, nomeadamente das crianças e dos adolescentes, tem como cenário fundamental, em grande medida, a escola (Singly, 2006) e exprime-se (também, mas não só) através de diversas opções escolares (Breviglieri, 2007).

Utilizando uma abordagem multidimensional, envolvendo métodos de tipo extensivo (inquérito por questionário) e intensivo (entrevistas individuais a alunos), este artigo pretende contribuir para uma análise mais holista das trajetórias escolares no ensino secundário, combinando dimensões institucionais com percursos e narrativas biográficas dos adolescentes que o frequentam.

Num primeiro momento, são clarificados os principais argumentos desta pesquisa: equaciona-se a escolha escolar no ensino secundário como prova biográfica (Martuccelli, 2006) e defende-se uma abordagem não restritiva do lugar do sucesso (escolar) na construção de projetos e trajetos trilhados na (e por intermédio da) escola. Com base nestas propostas teóricas e tendo como referência o ensino secundário, é então construída, num segundo momento, uma tipologia plural de

1 Entendemos aqui "individuação" enquanto processo de construção de uma singularidade biográfica (Beck, 1992 [1986]). Embora relacionado, não deve ser confundido com o conceito de "individualização", o processo societário de longa duração, em curso no mundo ocidental, que tem vindo a consagrar o indivíduo como sujeito. 
percursos escolares assente em dimensões objetivas (institucionais) e subjetivas (exploração e ajustamento biográfico). A partir dela apuram-se características sociais e académicas dos seus protagonistas e exploram-se subjetividades que subjazem ao processo de escolha. O artigo termina, por fim, com a sistematização dos principais resultados desta pesquisa.

\section{A escolha escolar como prova biográfica}

Em Portugal, e no caso de desejarem prosseguir os seus estudos, à entrada do secundário os estudantes são "convidados" a formular uma escolha escolar, idealmente autónoma (Dubet, 2002; Singly, 1996, 2004).

Ora, ao constituir-se elemento central de uma "prova" biográfica (Martuccelli, 2006; 2010) (no quadro de um processo de individuação em marcha), a escolha vocacional e o projeto (de futuro) que os jovens têm de construir estão longe de ser uma tarefa simples, pois têm de ser "desenhados" num dado tempo e num espaço, amplificado e desdobrado em inúmeras opções oferecidas pelo sistema (Maroy, 2002)² - embora desigualmente distribuídas pelo território nacional (Almeida e Vieira, 2006).

Ainda assim, e apesar dos constrangimentos que questionam a cada passo o ideário normativo da escolha livre e autónoma dos alunos, continuamos a estar perante um momento crítico de escolha e decisão, o que reveste esta passagem (do básico para o secundário) de uma enorme importância, quer para os percursos escolares quer para as trajetórias de vida como um todo. E isto pode ser tão ou mais problemático quanto o adolescente que é "forçado" a escolher está mergulhado num duplo processo de crescimento e amadurecimento (Breviglieri, 2007; Pappámikail, 2009). Exibirá, em muitos casos, uma identidade ainda muito provisória (hesitante ou dubitativa, nos termos de Breviglieri) quando tem de enquadrar a sua escolha num projeto de vida que dê forma e sentido àquilo que vai estudar, isto é, um projeto que vá ao encontro da obrigação (normativa) de buscar a mais plena realização de si (Taylor, 2009).

Este processo acarreta, portanto, algumas ambiguidades que merecem ser exploradas, nomeadamente aquelas que gravitam em torno de um incontornável paradoxo: de que forma as temporalidades institucionais (inscritas nas normas que regulam o sistema de ensino) se articulam com os tempos de construção de si, isto é, como se ligam as temporalidades institucionais com as biográficas?

Por um lado, as temporalidades institucionais, na sua concretização ideal, assentam num percurso linear, sem falhas, hesitações ou intermitências (retenções e abandonos). As estruturas dos sistemas de educação modernos plasmam, ainda hoje, um uso do tempo enquanto dimensão socializadora característico de uma

2 Aquando da realização deste estudo (2008/2009), o ensino secundário apresentava-se estruturado num espetro largo de opções vocacionais e requeria dos alunos uma orientação mais precisa dos percursos, ora para o prosseguimento de estudos, designados cursos científico-humanísticos - $\mathrm{CCH}$ - ou para uma mais rápida inserção no mercado de trabalho, de componente tecnológico-profissional, os denominados cursos tecnológicos e cursos profissionais - CTP. 
modernidade organizada (Wagner, 1996). Nesta o mecanismo de "diferimento de recompensas" constitui a base do "processo moderno de socialização" escolar (Leccardi, 2005: 35): ciclos sequenciais relacionados com idades-padrão, trajetórias predeterminadas e supostamente irreversíveis (Charbonneau, 2006) (isto é, opções não questionadas pelos alunos), etapas que se atingem superando outras previstas na estrutura curricular. Este mecanismo, ao assumir uma conceção linear de tempo, inspira uma dada conceção de sucesso escolar - medido e aferido de acordo com este modelo. Isto significa que, de uma perspetiva institucional, qualquer desvio desta norma - sequencial, linear e cumulativa - de trajetória escolar dos alunos é entendida como insucesso.

Por outro lado, devendo a escolha escolar implicar o sujeito num projeto de vida, entreveem-se algumas dificuldades, pois a busca de si, a construção de uma identidade e a definição de um projeto mais ou menos provisório de futuro em que o adolescente se reveja pode ocorrer a outros ritmos, não necessariamente compatíveis com o calendário institucional imposto pelo sistema. Na verdade, não se deve incorrer no erro de isolar o aluno das outras esferas da sua existência onde também se constrói, e onde a experiência é regulada por outras injunções normativas tão ou mais prementes do que a estritamente escolar, claramente orientada para o futuro, para a eficácia e para uma dada visão de sucesso. Os jovens tendem a estar profundamente engajados num processo de afirmação da sua condição juvenil, o que implica simultaneamente uma ancoragem ao presente, que é habitualmente acompanhada pela adoção de éticas de vida orientadas para a autenticidade, para a experimentação e para a celebração (do e no presente) de um hedonismo convivial, que emerge aliás como traço geracional (Pais, 1998; Ferreira, 2009). Com efeito, do ponto de vista relacional, o centramento nos grupos de pares constitui a integração nas redes amicais, numa missão em que muitos jovens se empenham, não raras vezes em detrimento do investimento no trabalho escolar (Jarvin, 2004; Pasquier, 2005; Pasquier, Buzzi e Cavalli, 2008). Uma dupla ancoragem (ao presente e ao futuro) que se traduz em dúvidas e hesitações, que podem ser compreensivelmente difíceis de gerir. Tanto mais que hoje o futuro emerge sobretudo como um território de incertezas.

Em suma, manter o futuro em aberto, suspender o tempo (Charbonneau, 2006) das escolhas definitivas, mesmo correndo o risco de possíveis reorientações vocacionais que impliquem retrocessos no percurso, pode constituir o desígnio de muitos. Desde logo para os bons alunos, cuja ambição é permanecer na escola com bons desempenhos de forma a manter ampliadas as margens de escolha (Dubet e Martuccelli, 1996), remetendo para um futuro longínquo (o ensino superior) um compromisso definitivo com uma opção vocacional. Depois, de todos aqueles (com melhores ou piores desempenhos) que ainda buscam a sua "verdadeira" vocação. Neste caso, a não linearidade das trajetórias escolares, ao invés de ser interpretada como insucesso, pode antes significar a condição necessária para a construção mais bem-sucedida da sua autonomia individual. Nesta perspetiva quem é, afinal, mais bem-sucedido? O indivíduo capaz de "ser verdadeiro consigo mesmo" (Taylor, 2009: 30), de procurar a sua autorrealização e perseguir os seus objetivos, não obstante um percurso escolar sinuoso? Ou o sujeito com um percurso linear e 
aparentemente bem-sucedido, mas que não se sente realizado nas suas escolhas (eventualmente mais "eficazes" mas produtoras de angústias biográficas)?

\section{Projetos, (in)sucessos e percursos plurais}

A ênfase conferida ao (in)sucesso escolar constitui, na verdade, uma questão relativamente recente.

Durante décadas, a permanência duradoura na escola dependia bem mais de causas sociais - resultantes de uma dada origem social e, muitas vezes, de uma condição de género - do que de resultados escolares. A questão do (in)sucesso escolar só emerge como problema social a partir do momento em que a massificação do ensino vem transformar radicalmente esta paisagem educativa. Agora, e por força da permanência duradoura de todos na escola, os diplomas académicos deixam de ser bens raros e a sua posse passa a ser requisito indispensável de acesso às posições sociais. É no interior da escola, através do desempenho académico e da orientação escolar a que ele conduz, que se ancora agora a seleção social - um dos princípios em que assenta a prova escolar.

A mobilização para o sucesso escolar passa a representar, desta forma, uma dimensão chave das práticas educativas das famílias e um desígnio que cada aluno é convidado a perseguir. Como bem explicita Glasman (2001), no atual contexto concorrencial já não basta apenas ir à escola, é também necessário ter bons resultados. E, idealmente, ter melhores resultados do que os outros - embora o contexto de crise atual questione a eficácia deste esforço. É justamente com o propósito de prevenção e combate ao insucesso escolar que o sistema de ensino tem vindo a pôr em marcha uma série de dispositivos de acompanhamento (diagnóstico, apoio, orientação, monitorização), que envolvem diferentes especialistas (Dionísio, 2009; Glasman, 2001) cuja intervenção pressupõe que o aluno se assuma como parceiro (Rayou, 2007) na prossecução de objetivos comuns.

Ora essa injunção institucional para o sucesso escolar investe cada jovem aluno de uma responsabilização acrescida - a responsabilização pelo seu eventual insucesso, mesmo que esta se alie a frustração ou arrependimento. E esta atribuição individual do desempenho é, afinal, expressão de um outro pilar associado à prova escolar: a produção da "confiança institucional em si" (Martuccelli, 2006). Contudo, este sentimento originado no julgamento escolar pode assumir vários matizes e declinar-se por efeito de composição de outros fatores. É importante não esquecer que a escola atual, tendencialmente massificada e programaticamente inclusiva, transporta agora consigo a promessa da reversibilidade do erro através da sua reparação - oferecendo ao indivíduo o ensejo de repetir (ilimitadamente?) provas, no presente ou no futuro, ao longo da vida, ou de trilhar percursos formativos alternativos. Nesta densa teia que a espessura temporal biográfica vai entretecendo, a prova escolar pode mesmo refratar-se em figuras mais híbridas (id., ibid.), complexificando os termos de que se constrói subjetivamente o sucesso a ela associado. Para alguns, o sucesso escolar pode vir a revelar-se responsável por alguns fracassos existenciais - quando a excelência escolar obtida dita a inevitabilidade de 
(per)cursos não verdadeiramente desejados. Para outros, o insucesso escolar pode estar na origem da descoberta de outros caminhos de sucesso - trilhados fora da escola. Mas essas "disritmias" (Pais e Ferreira, 2010) de tempos e modalidades (institucionais e subjetivas) de sucesso só reforçam a importância de uma abordagem não binária do lugar do sucesso (escolar) na construção dos percursos de vida na e através da escola.

\section{A construção de uma tipologia de percursos escolares}

Como afirmámos, uma noção plural de sucesso (escolar) introduz no estudo da individuação adolescente o confronto entre duas temporalidades distintas.

Por um lado, uma temporalidade institucional, imposta pelo sistema escolar, em que a escolha do aluno à entrada do ensino secundário (visto como livre, autónomo e capaz de se projetar no futuro) surge como um momento preciso que decorre de um percurso linear. O sucesso, nesta perspetiva, decorrerá da eficácia dessa escolha entrevista numa performance bem-sucedida.

Por outro lado, na outra temporalidade, a biográfica, a escolha surge antes de mais como um processo que decorre a montante e a jusante daquele momento preciso, ancorado aos tempos de construção de si por um sujeito que se experimenta e se divide por múltiplos territórios de existência. Neste caso, o sucesso será medido sobretudo pelo grau de ajustamento da escolha ao projeto identitário em construção.

Para testar estas hipóteses, recorremos a parte do material empírico recolhido ao longo do projeto "O Futuro em aberto: incerteza e risco nas escolhas escolares"(Projeto FCT n. ${ }^{\circ}$ PTDC/CED/67590/2006). Por um lado, socorremo-nos de resultados do inquérito por questionário aplicado em abril de 2008 ao universo de 1793 alunos que frequentavam o $10 .$. e o $12 .{ }^{\circ}$ anos de escolaridade em seis escolas secundárias públicas portuguesas, escolhidas em virtude dos perfis sociais e culturais contrastantes dos seus públicos. Por outro lado, mobilizamos dados resultantes da análise de 24 entrevistas semidiretivas recolhidas entre abril e maio de 2009 junto de 24 alunos (12 rapazes e 12 raparigas) de três das seis escolas da amostra (oito entrevistas por escola). ${ }^{3}$ Com vista a captar os processos de escolha e respetiva justificação, com base na acumulação de experiências às quais não é alheia a passagem do tempo, entrevistaram-se alunos do $10 .$. e do 12.. ano (12 entrevistas respetivamente). Importa salientar que cada entrevista

3 A seleção da amostra qualitativa procurou assegurar a diversidade social dos entrevistados e respetivas experiências escolares - associadas, também elas, aos constrangimentos da oferta escolar disponível a nível local. Com efeito, a primeira escola (A), localizada numa pequena cidade numa zona rural, recruta alunos de diversas origens sociais, embora maioritariamente oriundos das "classe média-baixa" ou "baixa", e oferece alguns cursos CCH e CTP. A segunda escola (B) situa-se num bairro residencial da capital e oferece apenas cursos $\mathrm{CCH}$ com vista ao prosseguimento de estudos. A maioria dos seus alunos provém de grupos sociais que se podem incluir nas "classes médias" e "altas". A terceira escola (C) está instalada numa antiga escola industrial da capital, e serve um público maioritariamente desfavorecido e oferece apenas cursos técnicos e profissionais. 


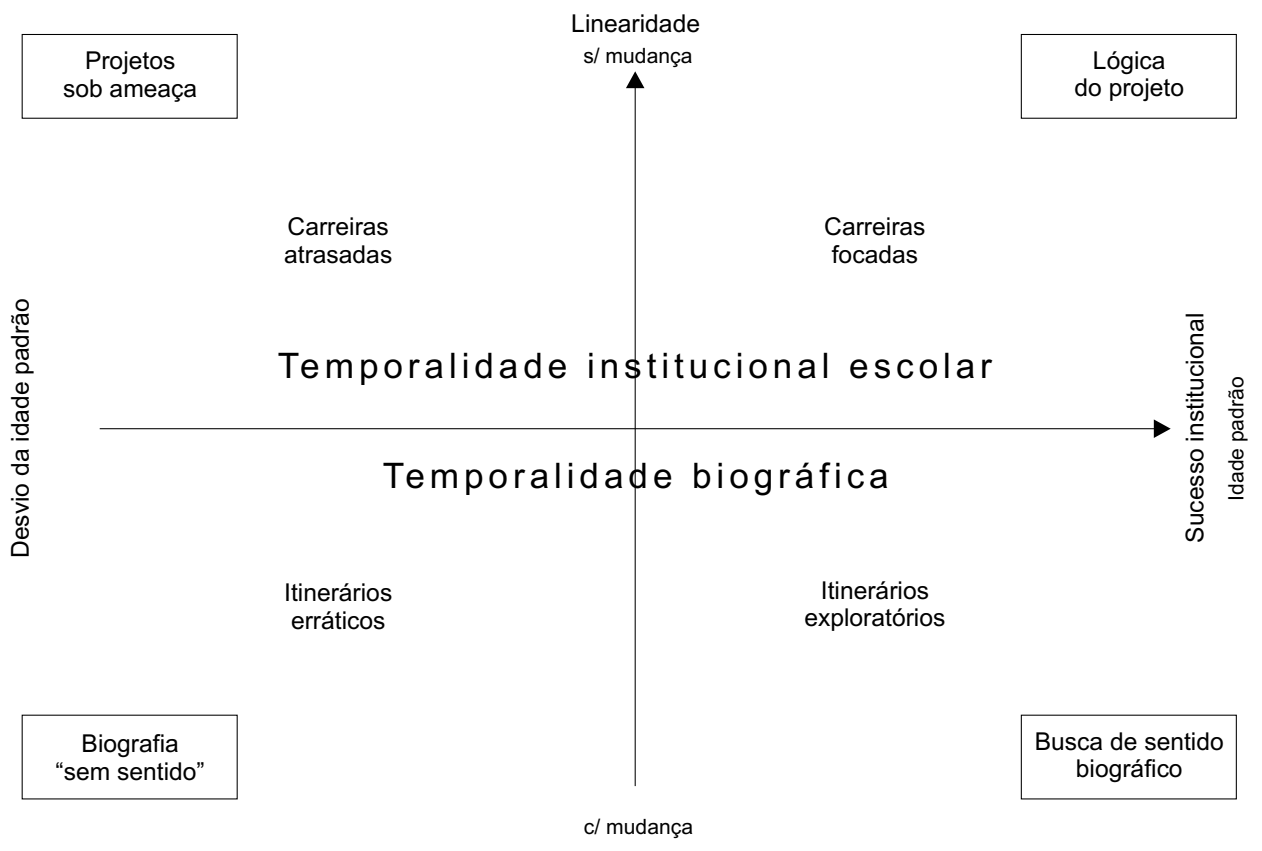

Figura 1 Modelo tipológico de percursos escolares

corresponde a uma narrativa de escolarização: explorou-se a vivência de toda a trajetória escolar, reconstituída pormenorizadamente, nomeadamente aferindo obstáculos, dilemas e justificações para escolhas passadas e futuras. Os planos de futuro e as redes de apoio foram elementos igualmente importantes retidos ao longo da entrevista.

Com base nos resultados preliminares construímos assim um modelo que procura precisamente enquadrar (heuristicamente) a tensão potencial entre temporalidades e o desenrolar dos trajetos individuais que permite a posteriori abordar as dimensões objetivas e subjetivas que lhes estão associadas.

Primeiramente cruzámos a linearidade do percurso (aferida a partir da existência ou não de mudança de curso e/ou escola) com o sucesso numa perspetiva institucional. Devido à ambiguidade conceptual e interpretativa que termos como "repetência" e "retenção", utilizados no questionário, pareceram gerar nos alunos inquiridos, optámos por tomar como indicador de sucesso institucional a correspondência da idade do aluno com a idade padrão de frequência dos anos escolares em análise (10. ${ }^{\circ}$ e $\left.12 .{ }^{\circ}\right)$. A coincidência indica que o aluno nunca repetiu nenhum ano ao longo do seu percurso (no básico e secundário), ao passo que quando se verifica um desvio (de um ou mais anos) é certo que o aluno repetiu, seja por insucesso no seu desempenho, seja por escolha voluntária em repetir um ano aquando, por exemplo, uma mudança de curso ou escola. Este indicador 
permite, pois, aferir objetivamente quais os alunos cujos percursos não registam intermitências ou retenções.

Num segundo momento, procurámos situar neste modelo as temporalidades dominantes: o ritmo mais institucional (tempo padrão, lógica linear e cumulativa) e o ritmo mais biográfico (exploratório, de ritmo individualizado). De reiterar, porém, que não se trata de ritmos mutuamente exclusivos, pois se é verdade que pode ocorrer uma divergência entre os ritmos institucionais e os biográficos de construção de si, também é verdade que em muitos casos haverá convergência, mitigando-se assim as tensões e os potenciais dilemas.

Ao invés de um percurso padrão (ideal - linear e sem repetência) e a sua exceção (linear, mas com repetência) abre-se assim espaço para abordar uma maior pluralidade de percursos.

Obtivemos quatro perfis distintos (figura 1).

No primeiro plano (acima do eixo das abcissas) encontramos as carreiras focadas e carreiras atrasadas, que funcionam segundo uma lógica do plano (ou seja, orientadas para a projeção no futuro) e estão sintonizadas pela temporalidade mais institucional. Designámos este primeiro conjunto de percursos carreiras porque, como salienta Martuccelli (2006: 423), o termo carreira evoca justamente uma lógica de promoção contínua que é indissociável de um sentimento de conquista de etapas (com maior ou menor sucesso).

Já no segundo plano (abaixo do eixo das abcissas) apresentam-se os itinerários exploratórios e os itinerários erráticos, os primeiros orientados pela busca de um sentido biográfico em que o (re)ajustamento da escolha vocacional não resulta necessariamente de um desempenho ineficiente mas antes de uma mais "feliz" expressão de si no projeto escolar, ${ }^{4}$ os segundos já marcados pela ausência de um sentido claro. Por contraste com a ideia de carreira, o vocábulo itinerário procura precisamente evocar, como acrescenta Martuccelli (ibid.: 243), a sinuosidade e o movimento errático de que estes trajetos se tecem. Itinerários serão, nesta perspetiva e ao contrário das carreiras (focadas e atrasadas), regulados sobretudo por uma temporalidade biográfica.

Veremos mais à frente que a noção de exploração e de procura de um sentido biográfico não exclui a incorporação de preocupações instrumentais, nem uma certa dose de manipulação do sistema educativo com vista à adequação permanente da opção escolar aos níveis de desempenho, restando assim uma larga margem de ajustamentos estratégicos que não decorrem necessariamente de uma submissão essencialista do projeto escolar ao projeto identitário...

Visto este modelo tipológico sob o prisma do grau de constrangimento a que cada tipo de percurso está sujeito (e todos estarão sujeitos a constrangimentos,

4 É importante assinalar que o itinerário exploratório envolve uma interrupção da trajetória inicialmente delineada (com mudança de escola e/ou de curso iniciado) por razões outras (como o "não gostar de várias disciplinas") que não o insucesso imediato. Eventualmente, tal mudança pode ter origem numa antecipação precoce, em função dos resultados escolares que se vão obtendo, das probabilidades (ou não) de entrada no curso inicialmente almejado, e da consequente exploração de outras alternativas. 
ainda que diversos), é possível afirmar que o desempenho escolar negativo (aqui medido a partir da divergência da idade padrão que pressupõe, algures no percurso, um desvio da norma - à esquerda do eixo das ordenadas) introduz uma maior dimensão de constrangimento, traduzida num crescente afunilamento institucional de opções possíveis (uma "orientação pelo insucesso" - Dubet, 2004) e num esfriar das expetativas escolares ou, em menor grau, no desenvolvimento do percurso sob ameaça de fracasso (na perspetiva institucional).

No plano oposto (à direita do eixo das ordenadas) verifica-se que o desempenho positivo (mais uma vez na perspetiva institucional, que aqui corresponde à sobreposição da idade do aluno com a idade padrão prevista) mantém ou alarga o leque de possibilidades escolares ou profissionais, inclusivamente de diferimento da escolha, sobretudo no caso das carreiras escolares que se pretendem longas (ou seja, adiar o compromisso com uma escolha profissional para o ensino superior). Esta liberdade de escolha pelo desempenho desdobra-se em duas possibilidades: uma que submete a construção biográfica à temporalidade escolar (não perder tempo) e a uma certa lógica da eficácia; e a outra que submete a temporalidade institucional ao desenvolvimento de um projeto identitário (sujeito a uma lógica de experimentação e a uma busca de sentido biográfico não compatível com a rigidez do calendário escolar imposto).

Este modelo não se esgota numa leitura estática e sincrónica dos percursos de resto, mesmo deste ponto de vista podem ocorrer sobreposições entre percursos, isto é, verificarem-se num dado momento situações híbridas do ponto de vista objetivo e narrativo -, o que reforça, a nosso ver, a sua aplicabilidade empírica enquanto mapa de leitura e enquadramento de percursos escolares. Com efeito, olhados estes percursos diacronicamente concluímos que pode existir mobilidade entre percursos. Uma mobilidade que é alimentada, sobretudo, pela experiência: uma carreira focada pode converter-se num itinerário exploratório, quando o aluno se confronta com disciplinas com que não se identifica; uma carreira marcada por retenções no ensino básico pode redundar num itinerário errático, quando más experiências se sucedem e o controlo sobre as opções diminui (constrangimentos institucionais) num movimento centrífugo que empurra o aluno para as margens do sistema ou para lá das suas fronteiras.

Com efeito, além destes percursos evidenciados pela tipologia, todos eles de prosseguimento dos estudos, há ainda um outro que não coube nesta pesquisa nem é espelhado neste modelo, mas que importa referir: trata-se do percurso de abandono da escola. Frequentemente assente na articulação e acumulação de múltiplos constrangimentos (económicos, culturais, académicos) que pesam por vezes de forma extrema sobre os indivíduos, não se pode aqui em bom rigor falar verdadeiramente de escolhas...

Resta, pois, texturizar este modelo com os dados empíricos recolhidos.

A distribuição dos alunos da nossa amostra $\left(10 .^{\circ}\right.$ e $\left.12 . .^{\circ}\right)$ pelos percursos-tipo assim desenhados revela uma prevalência quase maioritária (48,3\%) do percurso-norma (figura 2).

Se somada a sua exceção (as carreiras atrasadas) verifica-se que este tipo de percursos ascende aos três quartos da amostra, o que significa que a grande maioria dos 


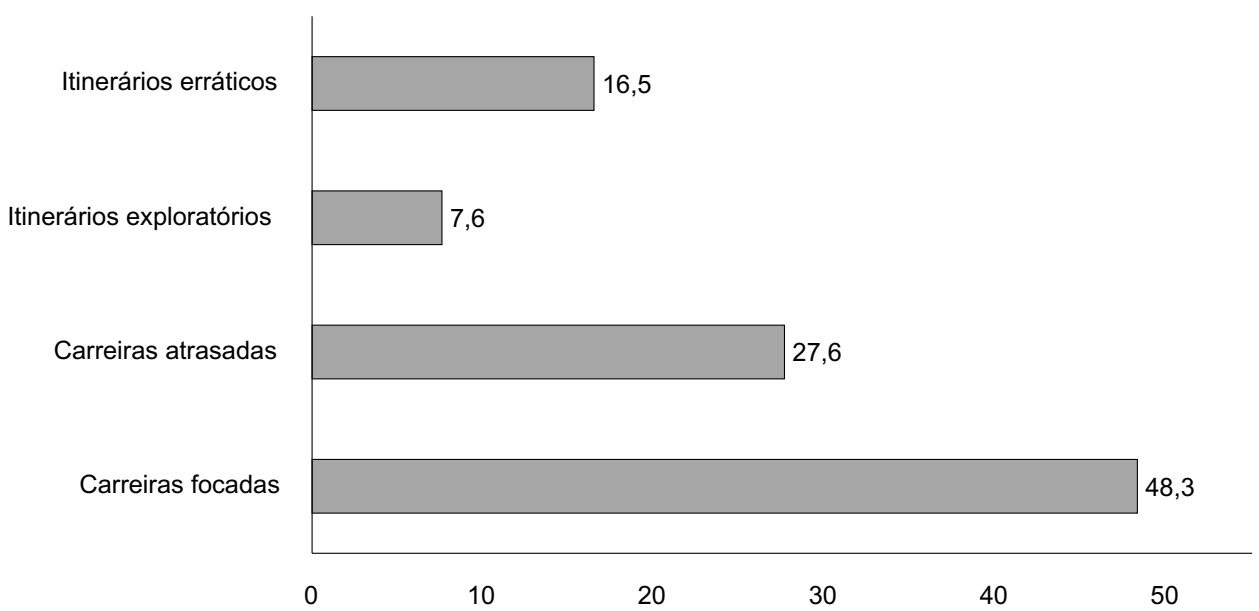

Figura 2 Modelo tipológico de percursos escolares: $10{ }^{\circ}$ e $12 .^{\circ}$ anos (\%)

Fonte: Inquérito aos alunos 2007/2008 - ICS.

alunos inquiridos estão de alguma forma sintonizados com a lógica escolar. Por sua vez, uma minoria relativa $(24,1 \%)$ trilha outros percursos, mais divergentes do padrão institucional. Todavia, o facto de serem minoritários e por isso menos representativos daquilo que parecem ser os trajetos mais frequentes não lhes retira importância. O que não têm de representativos têm de significativos para a caracterização quer de emergentes quer de tradicionais fenómenos sociais e culturais (porventura relativamente marginais no quadro do sistema de ensino, embora em espetros opostos, uns de reprodução e outros de inovação). Fenómenos que se traduzem em experiências vividas por um número não negligenciável de adolescentes por nós inquiridos.

No caso dos itinerários erráticos (16,5\%), encontramos alunos marcados pelo insucesso académico a que se associam aparentes dificuldades de navegação no sistema. São, entre os alunos inquiridos, aqueles mais próximos da exclusão/abandono do projeto escolar, como se revela nas palavras de Paula, quando interrogada sobre uma eventual mudança de curso para uma outra área mais motivante:

Não dá... não tenho possibilidades disso, já perdi três anos da minha vida e não vou estar a perder mais um. Então...é continuar neste, é até me fartar, depois me fartando lá vou trabalhar na área que tirei o outro curso. [Paula, 19 anos, 10. ano, curso profissional, escola A]

Já no caso dos itinerários exploratórios, a exploração de percursos alternativos (não necessariamente motivada pelo insucesso) parece ser feita dentro do sistema, o que aparentemente significa que a rejeição da temporalidade escolar não quer dizer falta de empenho no projeto escolar. 
Sim... o meu instinto era ir para Artes mas depois fui mais pela opinião dos outros e não sei quê e escolhi Humanidades, mas como não gostei...pois era só aulas teóricas e não sei quê e assim Artes... sempre desenho, e gostei mais de Artes... e mudei [...] nesse mesmo ano eu mudei... estava a fazer uma coisa que eu não gostava e então [mudei]... [Maria dos Anjos, 18 anos, 12. ${ }^{\circ}$ ano, curso profissional, escola A]

\section{Protagonistas: um retrato...}

Identificada a pluralidade de percursos, interessou-nos perceber quem são os seus protagonistas. Quando se observa a distribuição dos tipos de percurso por sexo dos alunos, verificamos que o desempenho negativo, com todas as consequências que daí advêm em termos de liberdade de escolha, constrangimento institucional e afunilamento dos percursos escolares, afeta mais os rapazes. Este resultado vem, de resto, ao encontro de uma tendência já identificada em muitos outros estudos (Almeida e Vieira, 2006; Duarte e outros, 2008; Grácio, 1997; Ribeiro, 2007; Silva, 1999) reveladores de uma dupla vantagem escolar (em termos de desempenho e de longevidade de percurso) conquistada pelas raparigas no sistema educativo português nas últimas décadas. No caso dos percursos marcados por alguma forma de insucesso as diferenças entre rapazes e raparigas, em desfavor dos primeiros, ascendem a 7,6 (carreiras atrasadas) e 11,6 pontos percentuais (itinerários erráticos). Não sendo novidade que o insucesso escolar é vivido mais no masculino, não deixa de ser interessante verificar que nos percursos mais bem-sucedidos numa perspetiva institucional a distribuição é mais equitativa (ainda que beneficiando as raparigas em 5,6 pontos percentuais). Já a sobrerrepresentação destas nos itinerários exploratórios (em mais 15,6 pontos percentuais) permite questionar a tese de que as raparigas, aderindo mais facilmente a uma lógica conformista, seriam pouco dadas à exploração...

Abordar os percursos de individuação a partir de uma perspetiva de sucessão de provas realçou o papel da experiência no diálogo constante que estabelece com os processos de construção de si. Não é por isso de estranhar o peso que o desempenho revelou na modelação dos percursos, visível na distribuição por tipo de curso que se apresenta nas figuras 4 e 5 .

Verifica-se, sem grande surpresa, que as carreiras focadas, independentemente do ano em que aluno se encontra, são sobretudo protagonizadas pelos alunos dos $\mathrm{CCH}$, o que é coerente com o perfil curricular desta via de ensino, orientada para a prossecução dos estudos e baseada em saberes de cariz mais académico. Por contraste, os itinerários erráticos são praticamente reservados aos alunos de cursos profissionalizantes. Este dado parece comprovar pistas teóricas e evidências empíricas já consolidadas, nomeadamente a de que a oferta institucional de fileiras educativas constitui uma forma de organização e hierarquização dos alunos, apresentando-se em alguns casos os CTP como solução de recurso para os já marcados pela experiência do insucesso. Essa evidência afirma-se, de resto, à escala nacional (Duarte e outros, 2008): a "orientação pelo insucesso" justifica-se escolarmente por aquilo que o aluno não tem, não em função daquilo que 


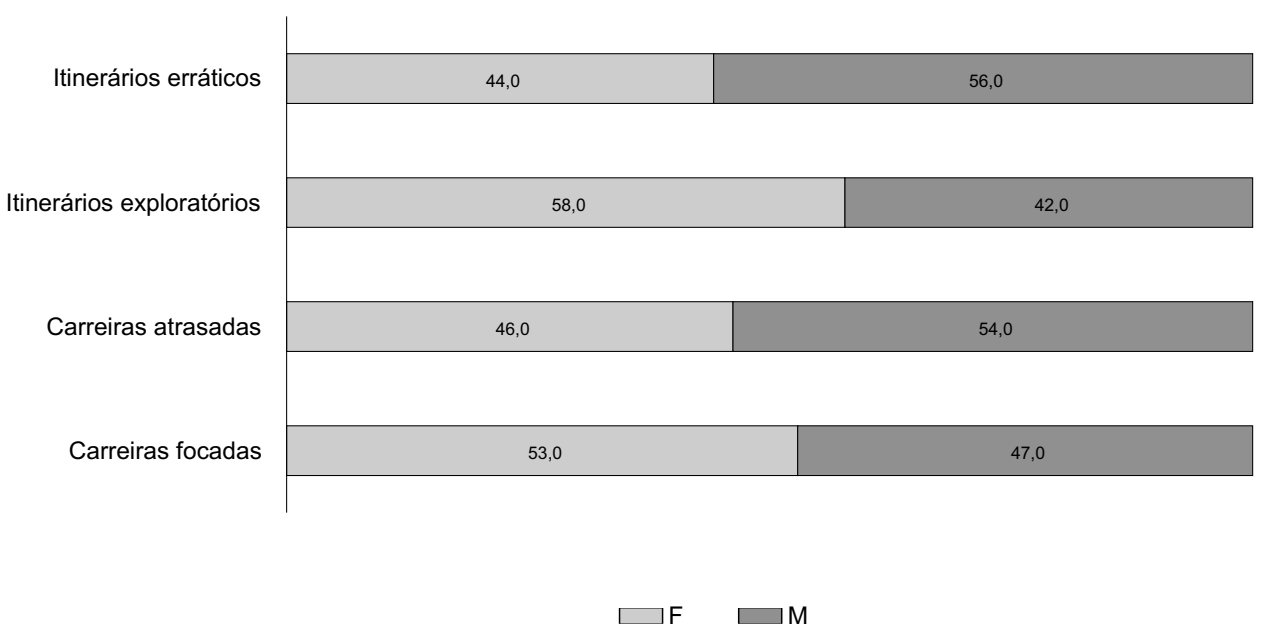

Figura 3 Tipo de percurso $\left(10 .^{\circ}\right.$ e $12 .^{\circ}$ ano, por sexo) (\%)

$\chi^{2}(3)=12,96 ; p<0,01$

Fonte: Inquérito aos alunos 2007/2008 - ICS.

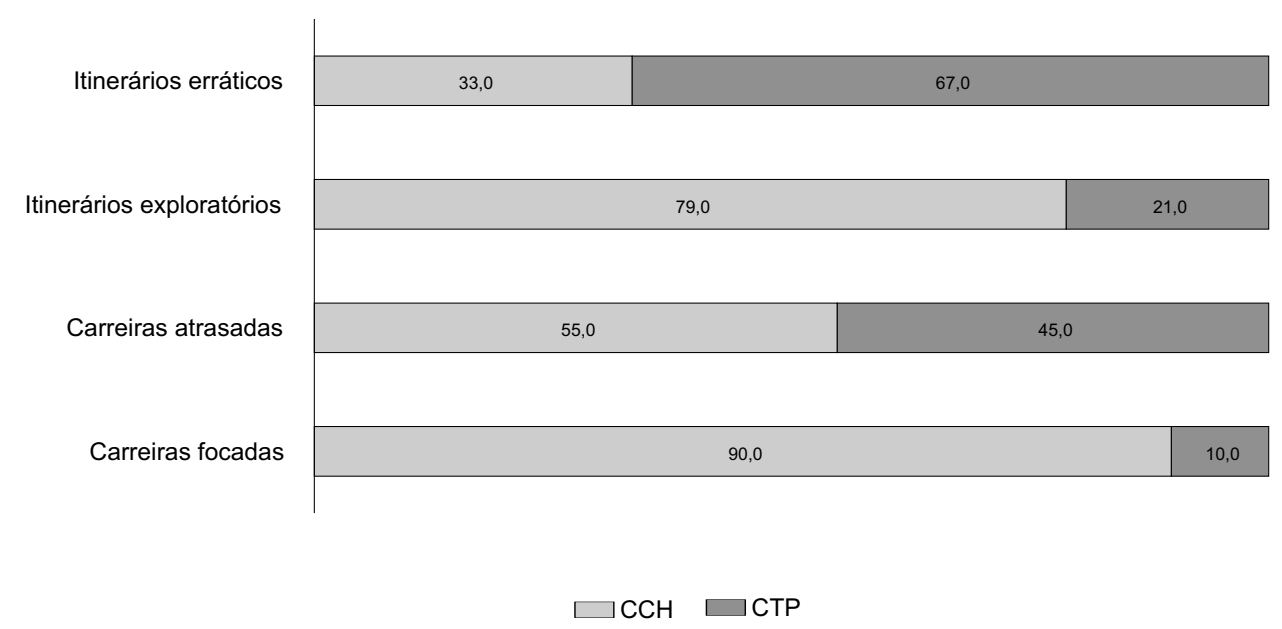

Figura 4 Tipo de percurso, por tipo de curso (10. ${ }^{\circ}$ ano) (\%)

$\chi^{2}(3)=239,35 ; p<0,001$

Fonte: Inquérito aos alunos $2007 / 2008$ - ICS. 


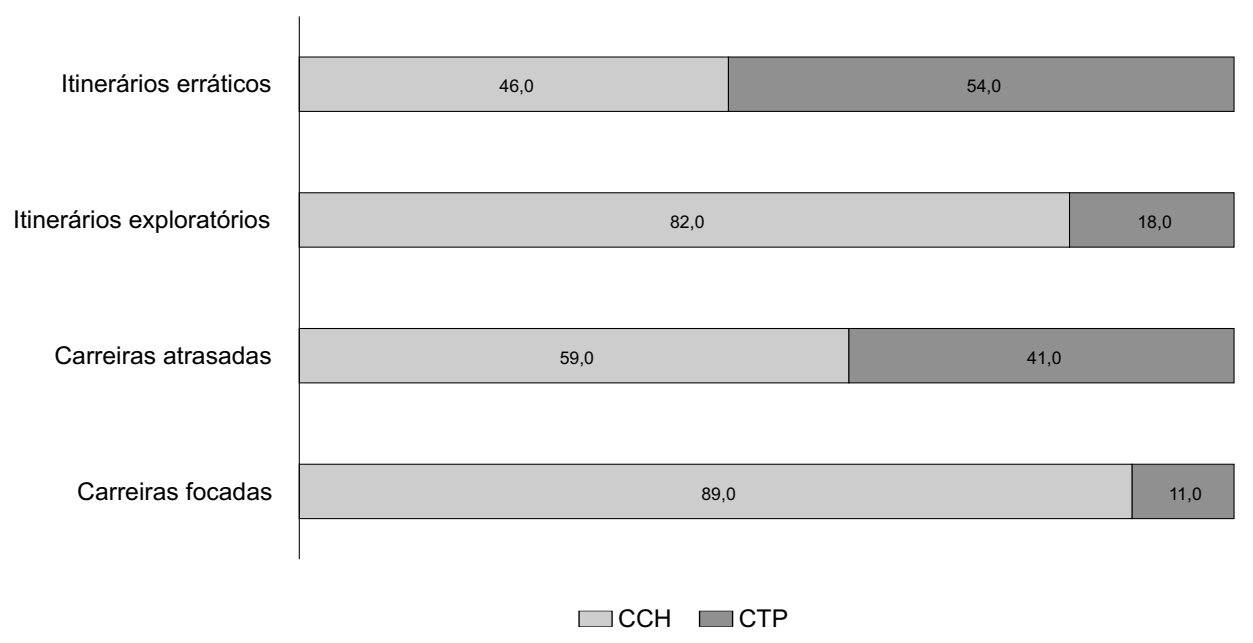

Figura 5 Tipo de percurso, por tipo de curso (12. ${ }^{\circ}$ ano $)(\%)$

$\chi^{2}(3)=114,99 ; p<0,001$

Fonte: Inquérito aos alunos 2007/2008 - ICS.

o aluno procura ou deseja, o que mais uma vez desafia o discurso ideológico em que se baseia todo o sistema...

Do mesmo modo se verifica que os itinerários exploratórios são protagonizados preferencialmente pelos alunos dos $\mathrm{CCH}$ (que, como se sabe, em média têm origens sociais relativamente mais favorecidas - Duarte e outros, 2008) e são potenciados com o avançar no ensino secundário (passam de $79 \%$ no $10 .^{\circ}$ ano para $82 \%$ no $12 .{ }^{\circ}$ ) à medida que a experiência escolar confronta os jovens com o conteúdo objetivo das suas opções. Não se tratará, porém, de uma associação linear entre experiências individuais e (re)formulação de escolhas, pois se a adesão a éticas de vida em que os valores do individualismo expressivo ocupam um lugar de destaque está relativamente disseminada, os meios que permitem concretizar esses modelos normativos de indivíduo estão desigualmente distribuídos, como se sabe. A figura 6 demonstra precisamente que os percursos não são fabricados ao acaso e não deixam de estar ancorados ao volume de recursos disponíveis na família.

No sentido de aprofundar e testar esta hipótese tomou-se a escolaridade dos pais como proxy da complexa aferição dos contextos socioeconómicos de origem dos alunos e cruzámo-la com os percursos escolares. Desse cruzamento se conclui que, efetivamente, é em relação aos percursos escolares mais próximos do padrão institucional de sucesso (carreiras focadas) que a proporção de alunos com background familiar mais escolarizado ( $40 \%)$ se revela superior. Também para os alunos com itinerários exploratórios esta proporção se revela comparativamente superior (50\%). Inversamente constatamos que é em relação aos percursos escolares mais vulneráveis do ponto de vista institucional (carreiras atrasadas e itinerários erráticos) que a proporção de alunos provenientes de famílias com menores recursos 


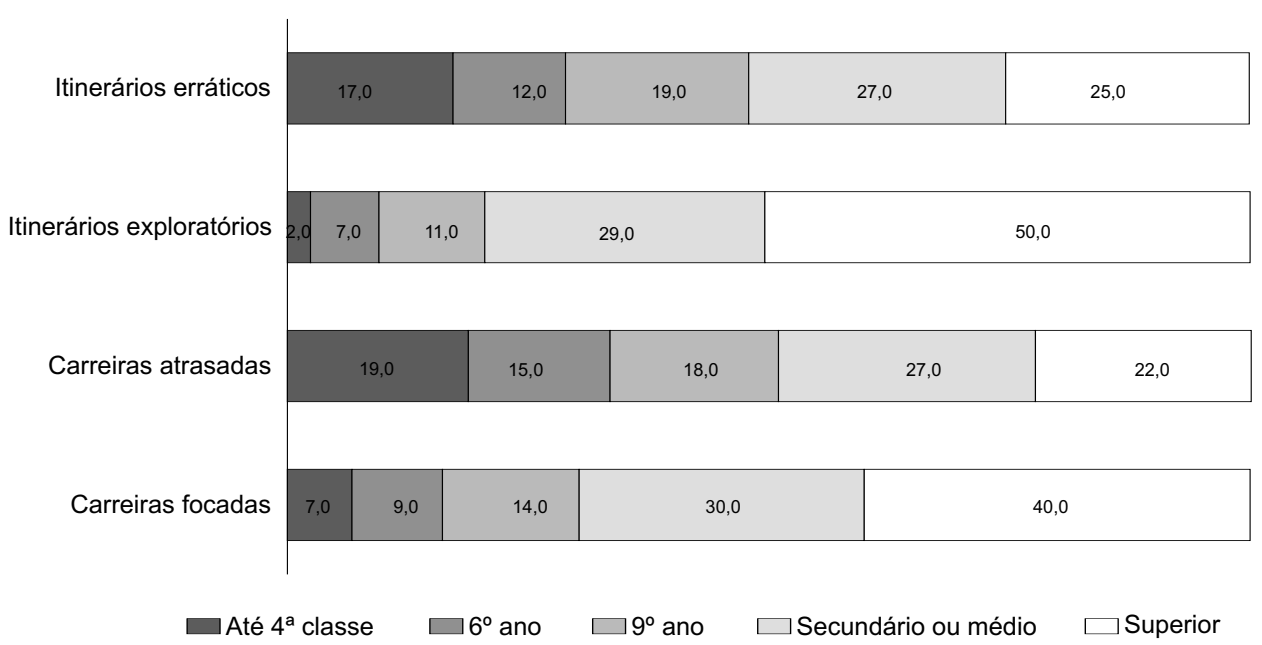

Figura 6 Tipos de percurso por escolaridade mais elevada dos pais (\%)

$\chi^{2}(3)=120,14 ; p<0,001$

Fonte: Inquérito aos alunos 2007/2008 - ICS.

escolares (até quatro anos de escolaridade) se mostra superior - 19\% e $17 \%$, respetivamente.

Mas, por outro lado, a figura 6 evidencia, igualmente, algum grau de capacitação dos alunos para além dos constrangimentos estruturais, uma vez que em todos os contextos sociais coexistem diferentes tipos de percursos, relevando a importância do desempenho individual apesar dos constrangimentos que afetam mais uns e as oportunidades que beneficiam mais outros. De salientar que os percursos escolares mais próximos do padrão institucional de sucesso (carreiras focadas) incluem uma proporção razoável (16\%) de alunos cujos pais detêm até ao máximo de seis anos de escolaridade. Por sua vez, os percursos escolares mais sinuosos e marcados por alguma desorientação (itinerários erráticos) atingem uma proporção não negligenciável ( $25 \%$ ) de alunos cujos pais atingiram o ensino superior.

Estes resultados vão justamente na direção das propostas analíticas defendidas por Martuccelli (2006), segundo as quais os processos de individuação se situam no cruzamento de constrangimentos associados a uma dada posição estrutural e de diferenciais capacitadores (estados sociais) que cada sujeito pode acionar para enfrentar as provas. Estes diferenciais compõem-se de vários elementos - competências cognitivas distintas, diversidade de meios práticos (ou "amortecedores", como os direitos sociais, os recursos, as ajudas e os suportes) de que se pode dispor e, ainda, o controlo que se tem sobre o decurso das provas. Ora, a ênfase nos percursos (e na sua natureza), apesar de ancorada à partilha desigual de riscos que as posições sociais comportam, não se esgota nela. A diversidade social interna de percursos assim o demonstra: a inscrição individual através das provas dadas no 
sistema escolar evidencia a elasticidade que os estados sociais emprestam ao processo de individuação.

\section{Escolhas e decisões: subjetividades, contextos e processos}

Apresentados os protagonistas dos percursos nos aspetos que melhor determinam a sua posição social, importa agora abordar as subjetividades subjacentes ao processo de escolha, no sentido de ultrapassar a dimensão factual e assim aceder à própria experiência da escolha. Convidados a situar a sua opção à entrada do secundário face a uma série de cenários hipotéticos relativos ao processo de definição vocacional (numa escala de 1 a 5 em que 1 corresponde a "não se aplica nada" e 5 a "aplica-se totalmente") os protagonistas destes percursos apresentaram algumas convergências, quer ao nível dos contextos de escolha, quer ao nível dos fatores e valores que tomaram em consideração nesse momento.

Os valores máximos e mínimos registados neste conjunto de perguntas apontam sobretudo para o facto de os jovens inquiridos sentirem que a sua escolha foi totalmente livre, e nada constrangida pelos pais e pouco ou nada influenciada pelos pares, média ou professores, o que reforça a assunção por parte dos indivíduos da responsabilidade e autonomia sobre a sua opção singular ao nível dos discursos, indiciando igualmente a incorporação da própria ideologia do sistema educativo, que não é questionada. Mas, mais do que a "frieza" destes indicadores estatísticos, foram essencialmente os testemunhos qualitativos a reforçar estas narrativas de livre escolha, apesar dos constrangimentos que diferentemente pesam sobre cada um dos jovens e que se refletem no grau de liberdade de que efetivamente dispõem. Seguem-se alguns exemplos.

Salvador, a frequentar, por opção, o $12 .^{\circ}$ ano do $\mathrm{CCH}$ de ciências e tecnologias numa escola secundária em Lisboa, apesar de viver em Vila Franca de Xira, reafirma uma escolha há muito construída com base numa "vocação" puramente individual

Eu decidi prosseguir os estudos porque desde pequeno sempre quis ser veterinário, e sempre tive esse sonho...

mas que, na realidade, se forja no cruzamento da "naturalização", no seio da família, do prosseguimento dos estudos até ao superior, e da inserção num contexto de socialização propício ao contacto com profissionais do ramo

- Tinha sempre esse sonho, mas eu falei com os meus pais e os meus pais têm amigos relacionados com a veterinária

- De onde é que veio [esse gosto] ...

- Não sei, sempre gostei de animais, tenho uma casa bastante grande e sempre tive animais, sempre gostei de animais, o meu pai tem uma profissão ligada aos animais, sempre que visitava quintas de amigos tinha sempre animais. [Salvador, 18 anos, $12 .{ }^{\circ}$ ano, curso $\mathrm{CCH}$ ciências e tecnologias, escola B] 


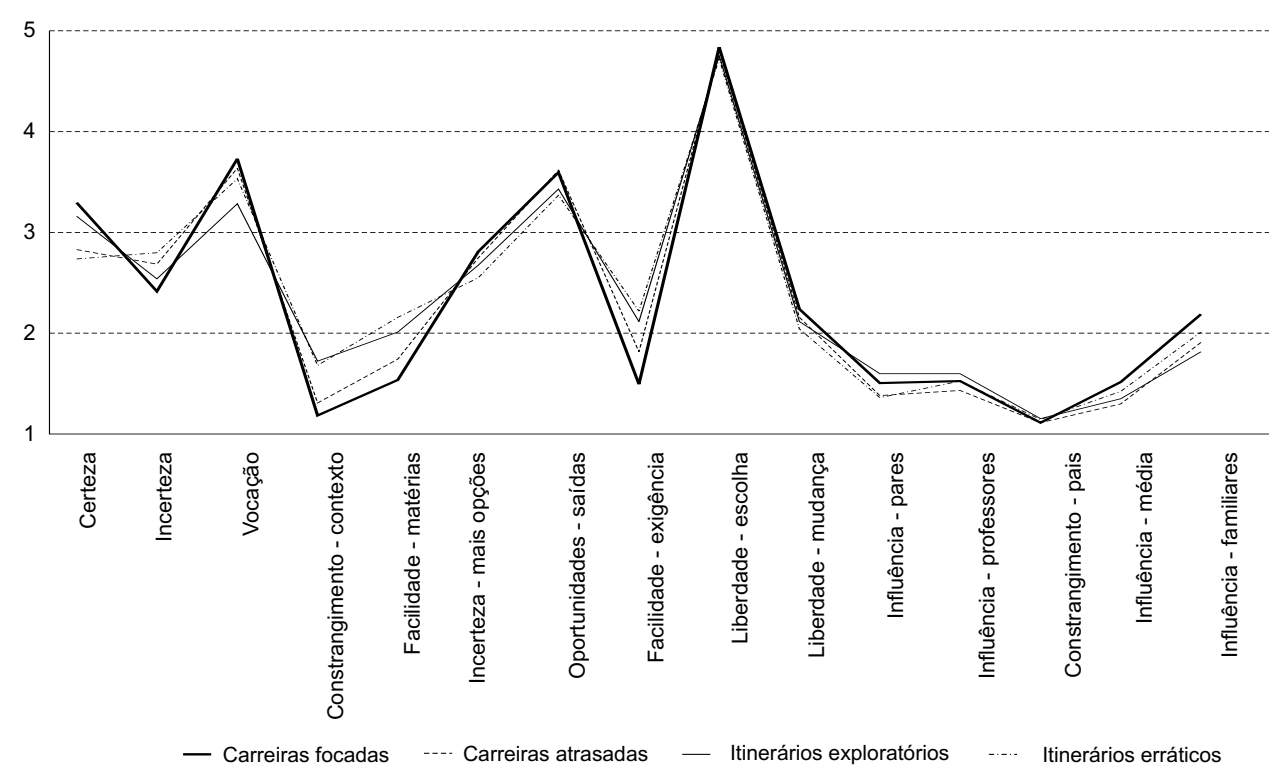

Figura 7 Fatores, valores e contextos determinantes das escolhas, por tipo de percurso (médias)

Escala: 1 (Não se aplica nada) a 5 (Aplica-se totalmente)

Nota: As diferenças foram testadas recorrendo ao Teste $F$ que se revelou estatisticamente significativo

$(a p<0,05)$ para a maioria dos itens, com exceção daqueles correspondentes às dimensões "incerteza - mais opções", "liberdade - mudança", "influência — professores", "constrangimento — pais" e "influência — média".

Fonte: Inquérito aos alunos 2007/2008 - ICS.

O testemunho de Carina revela-nos um percurso contrário, com o ajustamento $a$ posteriori do "gosto" a uma área curricular. A ausência de informação (nomeadamente no seu contexto familiar) para a elaboração de um projeto escolar ditou a construção passo a passo da sua "escolha", por tentativa e erro, ultrapassando inúmeros constrangimentos. Aluna de uma escola secundária de Lisboa com vocação profissionalizante desde o 3. ․ ciclo, nem sequer colocou a hipótese de mudar de escola na transição para o secundário. Para a sua escolha, e após realizar testes psicotécnicos pouco esclarecedores, começa por identificar um gosto inicial informática -, área na qual se pretende inscrever. Considerando que foi "mal informada" no momento da matrícula, viu-se colocada num curso de gestão de equipamentos tecnológicos com o qual não sentiu qualquer empatia.

E não gostava muito porque era, acho o curso mais coiso... Mais tipo... Eu achei o curso mais para rapaz do que para rapariga e então não me identificava...

A meio do ano, depois de assistir a algumas aulas de um curso afim (multimédia) frequentado por uma amiga da escola e ter gostado, decidiu falar com o conselho executivo para mudar de área. Mesmo forçada a repetir o 10.. ano para recuperar 
desse erro de escolha, não está arrependida dessa mudança, pois descobre a sua "autêntica vocação":

Não, eu estou a gostar porque acho que é uma coisa mesmo que, mudei de curso e acho que fiz bem mesmo mudar de curso, porque é uma coisa mesmo que eu gosto. [Carina, 17 anos, 10. ${ }^{\circ}$ ano, curso profissional de Multimedia, escola C]

Já no que diz respeito aos constrangimentos, o que emerge como mais premente é justamente o de natureza institucional (ofertas de cursos, áreas vocacionais por escola ou território educativo). Com efeito, apesar de a cotação neste indicador não ser muito elevada (de 1,23, em média, para as carreiras focadas, até 1,75 e 1,71 para as carreiras atrasadas e para os itinerários erráticos, respetivamente) o facto é que penaliza mais aqueles que já têm percursos débeis (com algum tipo de insucesso). Aqui reside precisamente um dos paradoxos do sistema: estamos perante um sistema educativo construído com base no princípio da escolha livre e individual, que responsabiliza o aluno por uma opção que este é na verdade constrangido a fazer, nomeadamente porque o sistema não oferece localmente todas as opções previstas. Tal é precisamente o caso de Rafael, aluno do 12.. ano do curso científico-humanístico de Humanidades numa escola de um concelho rural alentejano. $O$ leque limitado de opções oferecido pela escola, única secundária de todo o concelho, aliado à recusa dos pais da hipótese de frequentar o almejado curso profissional de informática noutra escola mais longínqua, empurra-o para uma escolha ziguezagueante - inscrição no $\mathrm{CCH}$ de ciências e posterior transferência para o cch de humanidades para "fugir à matemática" - para aí se obrigar a construir uma "vocação".

A Polícia Judiciária já pus de parte há algum tempo, pensei que me poderia dar alguma estabilidade, mas acho que não era mesmo isso que eu queria. Aqui... durante a minha estadia na secundária tive contacto com outras pessoas que se calhar me influenciaram noutras áreas. Então, pensei agora, há um tempo - no $11 .^{\circ}$ ano ainda em ciências políticas, talvez fosse essa área que eu gostaria de seguir. [Rafael, 18 anos, 12. ${ }^{\circ}$ ano, curso CCH de humanidades, escola A]

À procura de uma expressão quantitativa mais forte de algum grau de constrangimento, fomos cruzar estes elementos por tipo de cursos (CCH e CTP), e o que os dados nos revelam é que são estes últimos (alunos em média com percursos mais vulneráveis) a sentirem na pele mais dificuldades em encontrar o seu lugar no sistema. Com efeito, os resultados salientam que, em média, o constrangimento em relação ao curso em termos de contexto/oferta local pesou mais para os alunos de CTP $(1,96)$ no processo de escolha do que para alunos de $\mathrm{CCH}(1,27)$. Adicionalmente,

5 O caso desta entrevistada permite ainda demonstrar como um percurso cujas características o encaixam num itinerário errático se aproxima na realidade das características de um itinerário exploratório, pois a mudança de curso (por forma a verificar-se um melhor ajustamento ao "gosto" vocacional) forçou-a a recuar um ano (lido institucionalmente como insucesso) ainda que o recuo não se tenha devido a um mau desempenho. 


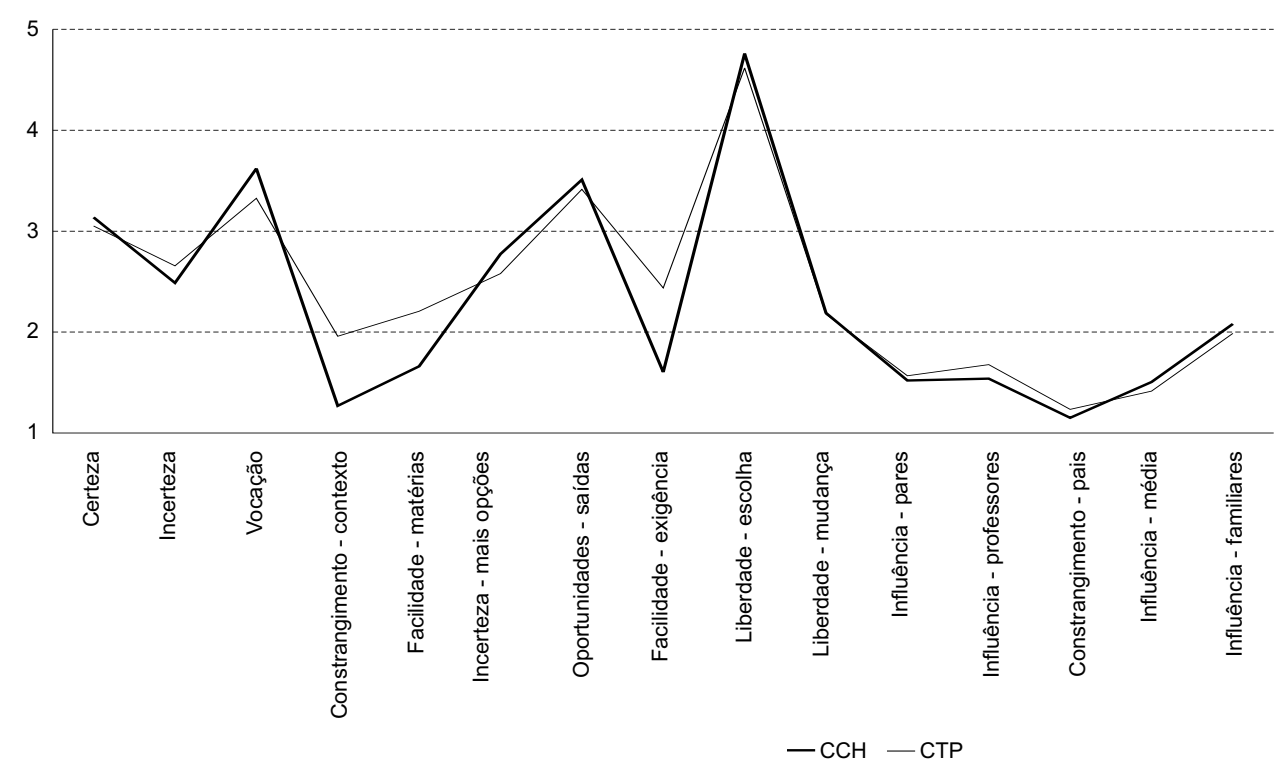

Figura 8 Fatores, valores e contextos determinantes das escolhas, por tipo de curso (médias)

Escala: 1 (Não se aplica nada) a 5 (Aplica-se totalmente)

Nota: As diferenças foram testadas recorrendo ao teste $T$ para amostras independentes que se revelou estatisticamente significativo $(a p<0,05)$ para a maioria dos itens, com exceção daqueles correspondentes às dimensões "certeza", "oportunidades — saídas", "liberdade — mudança", "influência — pares", "influência — professores", e "influência — média".

Fonte: Inquérito aos alunos 2007/2008 - ICS.

também para aqueles a dimensão que remete para o menor grau de exigência se revelou, em média, mais pertinente do que para os que frequentavam $\mathrm{CCH}(2,44$ e 1,60, respetivamente).

Isto não significa afirmar que outros alunos, como os de $\mathrm{CCH}$ (mais favorecidos de uma forma geral) não se deparem com constrangimentos, mas, como nos mostraram as entrevistas, dispõem de outro tipo de suportes e apoios que os ajudam a contornar estas dificuldades - nomeadamente facilitando a mobilidade, promovendo o "zapping escolar" (Langouet e Léger, 1997) entre estabelecimentos de ensino, caso se afigure necessário. Veja-se o caso de Margarida, boa aluna durante todo o período em que frequentou, no básico, um colégio religioso privado da capital. Antecipando que a passagem para o secundário iria elevar a níveis absurdos a fasquia da exigência, decide "mudar do privado para o oficial", contando com o apoio dos pais, apesar das expetativas iniciais da família (alargada) acerca da sua permanência no colégio.

- Foi, em grande parte foi minha... eles apoiavam a decisão porque eu acho que no privado forçam estudar muito mais... desnecessário porque também acho que é muito exigente... mas tem exigências que às vezes passam do normal e estamos a 
concorrer para entrar na faculdade e estamos a concorrer com pessoas de todo o lado, não são só com pessoas... do colégio... portanto achei que valia a pena trabalhar o mesmo e estar no oficial... acho que seria mais beneficiada e essa foi a grande questão. - os teus pais queriam que te mantivesses no colégio?

- A mãe e o pai... o pai não interferiu muito... mas por exemplo os avós... preferiam que eu me mantivesse no colégio... essa foi a grande questão do 9. ano... [Margarida, 18 anos, 12. ${ }^{\circ}$ ano, $\mathrm{CCH}$ de ciências socioeconómicas, escola B]

Um dos resultados da regressão logística (ver quadro 1) a que procedemos para testar esta hipótese é precisamente o facto de entre os principais fatores preditores de uma mudança de escola no secundário estar a escolaridade dos pais: quanto mais elevada for a escolaridade destes, maior a probabilidade de o aluno ter condições para mudar de escola, no sentido de ir ao encontro daquilo que são as suas opções.

É de referir que esta variável - o "capital escolar" familiar, tendo em conta o mais elevado de um dos pais - apresenta-se estatisticamente significativa apenas em relação à mudança de escola. Assim, uma condição social mais elevada tende a favorecer a mobilidade escolar quando ela é vista como útil ou necessária para melhorar o enquadramento social ou escolar do aluno face aos seus objetivos a médio prazo (escapar a uma iminente retenção ou obter médias mais elevadas para entrar em determinado curso ou instituição de ensino superior). Isso mesmo revela o testemunho de um aluno que habita uma quinta fora de Lisboa, indicando as razões para ter escolhido frequentar uma escola secundária no centro da capital, em detrimento da escola secundária local:

Não sei, eu moro em Vila Franca Xira, só que eu acho que em termos de ambientes... como sabe os ambientes são diferentes nas zonas do país, não é por não me identificar tanto, as pessoas são diferentes... não sei, não consigo explicar bem e eu estava mais identificado com as pessoas de Lisboa [...] e decidi vir para Lisboa, depois também no ensino superior quero entrar em Lisboa, não estou a pôr outra hipótese, se puser outra é estudar para fora [...] fora do país, Espanha ou EUA. Se não entrar em Lisboa. Basicamente foi isso, como Lisboa... pensar que se calhar era bom arranjar ambiente logo em Lisboa porque... ser mais aquele choque, o 1. ano, assim já se tem mais noção. [Salvador, 18 anos, 12.ํano, curso CCH de ciências e tecnologias, escola B]

No entanto, a mudança de escola, bem como a mudança de curso podem assumir diferentes contornos. Com efeito, a prática do zapping escolar pode decorrer de uma decisão própria do aluno e respetiva família - como se observa nas situações anteriormente invocadas - ou, ao invés, resultar da submissão à opção de outrem, por insuficiente domínio do sistema (ser transferido pela escola para outro estabelecimento de ensino...).

Ora, tanto para a mudança de escola como para a mudança de curso se registam diferenças estatisticamente significativas em relação ao tipo de curso frequentado e se o curso escolhido no $10 . .^{\circ}$ ano corresponde à primeira opção. Os 
Quadro 1 Preditores de mudança escolar e vocacional (regressão logística)

\begin{tabular}{|c|c|c|c|c|}
\hline & \multicolumn{2}{|c|}{ Mudança de escola ${ }^{(1)}$} & \multicolumn{2}{|c|}{ Mudança de curso ${ }^{(1)}$} \\
\hline & $\mathrm{B}$ & Wald & B & Wald \\
\hline Sexo & - & - & - & - \\
\hline Ano & 0,09 & $35,56^{\star \star *}$ & - & - \\
\hline Tipo de curso & 0,94 & $29,02^{* * *}$ & 1,45 & $58,84^{* * *}$ \\
\hline Curso $1 .^{a}$ opção & $-0,51$ & $6,56^{* *}$ & $-0,99$ & $26,3^{\star \star *}$ \\
\hline Repetência até ao $9 .^{\circ}$ ano & - & - & - & - \\
\hline $\begin{array}{l}\text { Nível de escolaridade dos pais } \\
\text { mais elevado }\end{array}$ & 0,12 & $10,96^{* * *}$ & - & - \\
\hline Nagelkerke $R^{2}$ & \multicolumn{2}{|c|}{0,09} & \multicolumn{2}{|c|}{0,14} \\
\hline
\end{tabular}

Nota: sexo ( $0-$ masculino; $1-$ feminino); ano $\left(0-10 .^{\circ}\right.$ ano; $1-12 .^{\circ}$ ano $)$; tipo de curso $(0-\mathrm{CCH} ; 1-$ CTP); curso 1. a opção $(0-$ não; $1-\operatorname{sim})$; repetência $(0-$ não; $1-\operatorname{sim})$.

(1) Mudança de escola / curso: 0 - não; 1 - sim. * $p<0,05 ;{ }^{* *} p<0,01$; ${ }^{* * *} p<0,001$

Fonte: Inquérito aos alunos 2007/2008 - ICS

alunos a frequentar cursos CTP são, mais do que os dos $\mathrm{CCH}$, aqueles para quem a mudança de escola ou de curso é mais provável. O mesmo sendo aplicável aos alunos que frequentam no 10. ano um curso que não corresponde à sua primeira opção. Dado os recursos de informação sobre o sistema de ensino serem, genericamente, mais limitados no caso dos contextos familiares e sociais dos alunos que frequentam os CTP, pode-se legitimamente aventar que a mobilidade ocorrida no interior do sistema decorrerá, neste caso, do próprio desconhecimento do sistema. O testemunho de Carina sobre os equívocos que a levaram a frequentar um curso profissional (de gestão de equipamentos tecnológicos) com o qual não se identificava é elucidativo deste ziguezaguear no sistema sem grande rumo.

Eu acho que fui um bocado mal informada ao princípio, porque eu quando fui fazer a minha inscrição eu expliquei o que queria e havia dois cursos e então, depois eu expliquei, e a senhora disse-me, e eu depois vi que não era bem aquilo que eu queria e então acho que também fui um bocado mal informada. Mas pronto... [Carina, 17 anos, 10. ano, curso profissional de multimédia, escola $\mathrm{C}]$

Assim sendo, poder-se-á falar de duas lógicas de mudança: uma voluntária e eventualmente estratégica e outra (in)voluntária e tendencialmente errática (ao sabor da maré). Ou seja, uma enforma os percursos exploratórios, outra alimenta os percursos erráticos...

Todavia, os constrangimentos não se reduzem à dimensão institucional de oferta. Como temos vindo a sublinhar, o próprio veredito escolar condiciona grandemente as escolhas: verifica-se ainda na figura 7 que fatores como a facilidade das 
matérias ou a exigência dos cursos pesam diferenciadamente para os diferentes protagonistas destes percursos. É justamente para os alunos que estão relativamente mais perdidos no sistema (marcados pelo insucesso e/ou pela falta de um sentido claro para os seus estudos) que estes fatores são mais relevantes no momento de fazer a escolha (itinerários erráticos e carreiras atrasadas).

Apesar de as diferenças serem algo tímidas, não nos surpreende o facto de serem alunos com carreiras focadas aqueles que mais certeza sentiram no momento de tomar a decisão (porque muitos sempre souberam o que queriam seguir). Do mesmo modo são preferencialmente alunos a desenvolver itinerários exploratórios que declaram algum tipo de indecisão no momento da escolha. Tal como também nos vieram a demonstrar as entrevistas, o compromisso com uma escolha mais definitiva é remetido para o futuro, optando no secundário por cursos que ofereçam maior leque de opções futuras no caso de haver dúvidas no momento da decisão. Esta é aliás uma das formas preferenciais de lidar com a incerteza, como está patente no testemunho de um dos entrevistados. Indeciso entre o $\mathrm{CCH}$ de humanidades e o de ciências socioeconómicas, por gostar de línguas e história, mas ao mesmo tempo "ser mais para números", decide optar pela segunda hipótese, já validada institucionalmente como a melhor decisão - "pelos vistos acho que foi a melhor, porque as minhas notas mais altas são às específicas, quer dizer que estou bem integrado na área" - e que lhe abre um leque mais amplo de possibilidades de escolha:

- Tenho três hipóteses.

- Ai é?

- Direito, relações internacionais ou gestão hoteleira [...], por acaso acho que ia gostar imenso, é todo o meu género. Gostava imenso de ir para Gestão Hoteleira, mas ao mesmo tempo gostava de ir para relações internacionais, porque sempre gostei imenso e acho que tenho jeito, sempre tive à vontade a falar com as pessoas, e acho que é um bocado... género. Mas sei que sempre tive um bocadinho de jeito - é de família para advocacia, a minha família é toda advogada, desde os meus avós, menos a minha mãe, toda a minha família é advogada. [Martim, 16 anos, 10. ${ }^{\circ}$ ano, curso CCH de ciências socioeconómicas, escola B]

Na nossa perspetiva emerge sobretudo dos dados a tradução empírica do "paradoxo do projeto" como definido por Dubet e Martuccelli (1996): os mais bem-sucedidos academicamente e os alunos que mais meios têm para se projetar no futuro são os que mais tendem a delegar o seu futuro nos seus (bons) desempenhos escolares e a diferir para mais tarde a sua escolha (o secundário surge como antecâmara do ensino superior, para onde remetem o momento do compromisso vocacional mais definitivo); pelo contrário, aqueles que não revelam tais atributos são forçados a abraçar (mais precocemente) as únicas vias escolares que para eles estão disponíveis. Ou seja, as "narrativas de projeto" produzidas pelo sistema educativo obrigam a escolher e a ser responsáveis pelas suas escolhas justamente aqueles que menos possibilidades de escolha têm.

Por último, os percursos tendem a ser fabricados numa combinatória de referências normativas que à primeira vista podem parecer paradoxais, se acolhêssemos 
uma visão essencialista da "identidade" assente exclusivamente numa ideia pura de vocação autêntica e prévia à experiência. No quadro do singularismo societal que se vive na contemporaneidade (Martuccelli, 2010), essa ideia tornou-se a trama estrutural de perceção de si a partir da qual se entretecem as gramáticas que os indivíduos preferencialmente usam para comunicar narrativamente com os outros (Martuccelli, 2006: 334). Com efeito, o que os dados nos demonstram, e as entrevistas por seu turno confirmam, é que, se é verdade que a missão de se realizarem a si próprios na escolha vocacional que fazem é central nos seus discursos, isso não significa que o futuro não seja também ponderado de forma mais instrumental, ou seja, em termos de oportunidades de carreira. Vários são os testemunhos que o evidenciam: aliar o gosto desde "sempre muito vincado" por economia com a ideia de que prosseguir os estudos é "fundamental para conseguir uma vida melhor, principalmente em termos financeiros, e até mesmo sociais" [Cristina, 18 anos, 12. ${ }^{\circ}$ ano, CCH de Ciências Socioeconómicas, escola A]; ou seguir o que se quer - "direito" - com a obtenção dos melhores resultados visando um futuro profissional que se antecipa como competitivo - "hoje em dia é tudo tão competitivo, é preciso ir um bocado mais além" [José Maria, 19 anos, 12.. ano, CCH de humanidades, escola B]; ou ainda compatibilizar o gosto pela "área das tecnologias [...] por esses funcionamentos, essa transformação de energia para uma energia mecânica", com a descoberta, desde o estágio profissional, de que a faculdade pode trazer mais do que a vida inicialmente almejada de técnico numa fábrica oferece: "vou ficar sempre limitado ao facto de não poder assinar, acho que é isso que ir para a faculdade nos dá, poder assinar, sermos certificados para criar de certa forma e é isso que me agrada porque o espírito criativo é o criar as coisas" [Joel, 19 anos, 12. ano CTP de mecânica, escola C]. De salientar que a "capacidade" de antecipar as vantagens de um percurso encontra-se hoje seriamente afetada pela mutabilidade constante do mercado de trabalho, acrescida do problema da precariedade e do desemprego juvenil...

O que se vê então é a uma lógica de composição da narrativa de si próprios que procura articular subjetivamente diferentes desígnios normativos, igualmente importantes (Pappámikail, 2009). E este processo de articulação, que emerge também no confronto analítico entre o registo factual e o registo narrativo dos adolescentes entrevistados, denuncia as tensões que podem ocorrer no processo de construção biográfica.

Perspetivar a escolha como um processo que ocorre a montante e a jusante do momento em que a decisão é tomada reforça a importância de se perceber os contextos em que são feitas as escolhas, bem como as motivações e sentidos que lhes são atribuídos.

\section{Em conclusão}

Questionar uma abordagem restritiva, limitada, binária da noção de sucesso escolar constituiu o cerne deste artigo.

Começámos por identificar os pressupostos que enformam a (tradicional) definição institucional do sucesso, assente na imposição de uma temporalidade 
linear, sequencial, de trajetos-padrão escolares, segundo a qual se afere do progresso (ou não) de cada aluno. Desta abordagem estão ausentes considerações que levem em conta o facto de os percursos escolares - e as provas que neles se jogam estarem profundamente imbricados nos processos de individuação.

De facto, no caso dos adolescentes que prosseguem os estudos e que, por isso, são obrigados institucionalmente a escolher uma opção vocacional à entrada do secundário, as decisões tomadas podem confrontar-se com dúvidas, incertezas e questionamentos. A temporalidade biográfica, mais densa e potencialmente complexa, assente num processo subjetivo de exploração visando a busca (normativamente obrigatória) da plena realização de si pode colidir com a temporalidade institucional imposta no momento preciso da escolha. Adicionalmente há que contabilizar a volatilidade dos contextos sociais, económicos e políticos que, mesmo marginalmente, não deixam de interferir na avaliação pelos sujeitos daquilo que é uma escolha boa e/ou uma escolha certa, uma vez que não estão ausentes, como verificámos, preocupações com os aspetos mais instrumentais da escolha.

A partir do reconhecimento das potenciais tensões associadas às duas temporalidades, explorámos então um modelo de percurso escolar no secundário que permite dar conta das formas de acomodação, mas também de eventuais "disritmias" de tempos e modalidades (institucionais e subjetivas) de sucesso, plasmadas em quatro itinerários-tipo, entendidos numa perspetiva dinâmica as "carreiras focadas", as "carreiras atrasadas", os "itinerários exploratórios" e os "itinerários erráticos".

Os resultados do inquérito demonstram que uma boa parte dos alunos encontra-se em convergência, quer com o padrão-norma de sucesso escolar, quer com o seu inverso, ou seja, o padrão-norma do insucesso. Não obstante, o modelo permite também entrever outras modalidades de percurso - percursos mais agitados, pautados por mobilidade, ruturas, reversibilidades - que escapam à lógica escolar convencional e, por isso, de inegável interesse para entender modalidades (emergentes?) de relação com a escolaridade que questionam a noção institucional de sucesso. Curioso é notar que os protagonistas de cada um destes quatro percursos escolares se, por um lado, não se organizam ao acaso, demonstrando tendencialmente atributos sociais e académicos relativamente diferenciados entre si, o que parece evidenciar o peso dos constrangimentos sociais sobre a escolaridade, por outro lado, revelam igualmente margens de capacitação para, através dos seus desempenhos, contrariar semelhantes constrangimentos, o que fica demonstrado no facto de encontrarmos alunos com perfis diferenciados nos vários tipos de percursos.

Para lá dos percursos, fomos ainda perscrutar os sentidos que os protagonistas lhes conferem - para entender, assim, a avaliação subjetiva dos mesmos. À afirmação da livre escolha dos seus (per)cursos, que celebra os valores da autonomia individual e da realização de si a que estes alunos tão fortemente aderem, pelo menos narrativamente, contrapõem-se referências a alguns constrangimentos institucionais presentes (opções e cursos não disponíveis na escola frequentada) ou futuros (antecipação das diferentes oportunidades profissionais que cada opção oferece) que afetam a plena realização de sonhos e justificam, pelo menos 
em parte, o sentido dos percursos trilhados. Mais do que uma narrativa unívoca, é de uma composição de referências normativas (mais expressivas, umas, mais instrumentais, outras) que as escolhas e os percursos escolares tendem a ser fabricados.

\section{Referências bibliográficas}

Almeida, Ana Nunes de, e Maria Manuel Vieira (2006), A Escola em Portugal. Outros Olhares, Novos Cenários, Lisboa, Imprensa de Ciências Sociais.

Beck, Ulrich (1992 [1986]), Risk Society. Towards a New Modernity, Londres, Sage Publications.

Breviglieri, Marc (2007), “Ouvrir le monde en personne: une anthropologie des adolescences”, em M. B. V. Cicchelli (org.), Adolescences Méditerranéennes. L’Espace Public à Petits Pas, Paris, L'Harmattan, pp. 19-59.

Charbonneau, Johane (2006), "Réversibilités et parcours scolaires au Québec", Cahiers Internationnaux de Sociologie, CXX, pp. 111-131.

Dionísio, Bruno (2009), A Orientação no Plural. Promessas e Limites do Serviço Público de Orientação Escolar, Lisboa, Faculdade de Ciências Sociais e Humanas da Universidade Nova de Lisboa, dissertação de doutoramento.

Duarte, Maria Isabel, Cristina Roldão, David Nóvoas, Susana Fernandes, e Teresa Duarte (2008), Estudantes à Entrada do Secundário, Lisboa, Ministério da Educação, Gabinete de Estatística e Planeamento da Educação.

Dubet, François (2002), Le Déclin de l'Institution, Paris, Éditions du Seuil.

Dubet, François (2004), L'École des Chances. Qu'Est-Ce Qu'Une École Juste?, Paris, Éditions du Seuil / La République des Idées.

Dubet, François, e Danilo Martuccelli (1996), À l'École. Sociologie de l'Expérience Scolaire, Paris, Éditions du Seuil.

Ferreira, Vítor Sérgio (2009), "Ondas, cenas e microculturas juvenis", Plural, Revista do Programa de Pós-Graduação em Sociologia da USP, 15, pp. 99-128.

Glasman, Dominique (2001), L'Accompagnement Scolaire. Sociologie d'Une Marge de l'École, Paris, Presses Universitaires de France.

Grácio, Sérgio (1997), Dinâmicas da Escolarização e das Oportunidades Individuais, Lisboa, Educa.

Jarvin, Magdalena (2004), “Groupe de pairs et relations d'amitié", em C. Pugeault-Cicchelli, V. Cicchelli e T. Ragi (orgs.), Ce Que Nous Savons des Jeunes, Paris, Presses Universitaires de France.

Langouet, Gabrielle, e Alain Léger (1997), Le Choix des Familles. École Publique ou École Privée?, Paris, Éditions Faber.

Leccardi, Carmen (2005), “Por um novo significado do futuro: mudança social, jovens e tempo", Tempo Social, Revista de Sociologia da Universidade de São Paulo, 17 (2), pp. 35-57.

Maroy, Christian (org.) (2002), L'Enseignement Secondaire et Ses Enseignants, Bruxelas, De Boeck.

Martuccelli, Danilo (2006), Forgé par l'Épreuve. L'Individu dans la France Contemporaine, Paris, Armand Colin. 
Martuccelli, Danilo (2010), La Société Singulariste, Paris, Armand Colin.

Pais, José Machado (1998), Gerações e Valores na Sociedade Portuguesa Contemporânea, Lisboa, Instituto de Ciências Sociais e Secretaria de Estado da Juventude.

Pais, José Machado, e Vítor Sérgio Ferreira (orgs.) (2010), Tempos e Transições de Vida. Portugal ao Espelho da Europa, Lisboa, Imprensa de Ciências Sociais.

Pappámikail, Lia (2009), Juventude, Família e Autonomia. Entre a Norma Social e os Processos de Individuação, Lisboa, Universidade de Lisboa, dissertação de doutoramento.

Pasquier, Dominique (2005), Cultures Lycéennes. La Tyrannie de la Majorité, Paris, Éditions Autrement.

Pasquier, Dominique, Carlo Buzzi, e Alexandro Cavalli (2008), “Quelle culture adolescente? ", em Alexandro Cavalli, Vincenzo Cicchelli e Olivier Galland (orgs.), Deux Pays, Deux Jeunesses? La Condition Juvénile en France et en Italie, Rennes,

Presses Universitaires de Rennes, pp. 209-229.

Rayou, Patrick. (2007), “De proche en proche, les compétences politiques des jeunes scolarisés", Éducation et Sociétés, 19 (1), pp. 15-32.

Ribeiro, Ana Maria (2007), “A vantagem escolar das raparigas no secundário: resultados escolares e identidades juvenis numa perspectiva de género", em M. M. Vieira (org.), Escola, Jovens e Media, Lisboa, Imprensa de Ciências Sociais, pp. 109-135.

Silva, C. G. D. (1999), Escolhas Escolares, Heranças Sociais, Oeiras, Celta Editora.

Singly, François de(1996), Le Soi, le Couple et la Famille, Paris, Nathan.

Singly, François de (2004), Enfants-Adultes. Vers Une Égalité des Statuts?, Paris, Encyclopaedia Universalis.

Singly, François (2006), Les Adonaissants, Paris, Armand Colin.

Taylor, Charles (2009), A Ética da Autenticidade, Lisboa, Edições 70.

Wagner, Peter (1996), Liberté et Discipline. Les Deux Crises de la Modernité, Paris, Éditions Métailié.

Maria Manuel Vieira. Investigadora no Instituto de Ciências Sociais da Universidade de Lisboa e coordenadora do Observatório Permanente da Juventude no mesmo instituto. E-mail: mmvieira@ics

Lia Pappámikail. Professora adjunta convidada da Escola Superior de Educação do Instituto Politécnico de Santarém e assessora da direção do Observatório Permanente da Juventude do Instituto de Ciências Sociais da Universidade de Lisboa. E-mail: lia.pappamikail@ese.ipsantarem.pt

Cátia Nunes. Técnica superior de estatística no Instituto Nacional de Estatística e colaboradora em projetos do Instituto de Ciências Sociais da Universidade de Lisboa. E-mail: catia.nunes@ine.pt 


\section{Resumo/abstract/résumé/resumen}

Escolhas escolares e modalidades de sucesso no ensino secundário: percursos e temporalidades

A obrigação de frequentar a escola, por um período de tempo cada vez maior, transformou a escolarização numa dimensão crucial da construção biográfica. A transição para o ensino secundário revela-se, neste aspeto, um momento particularmente crítico, uma vez que o jovem é convidado a definir um projeto (de futuro), através duma escolha de via escolar. Ora, ocorrendo numa etapa da vida - a adolescência - caracterizada pela adesão a uma ética de exploração, esta projeção no futuro pode levar a uma tensão entre ritmos biográficos (baseados na exploração) de construção de si e calendários institucionais (baseados na obrigação de escolher) impostos pelo sistema de ensino. Neste artigo, propomos um modelo de trajetórias escolares no ensino secundário que leva em conta tais tensões.

Palavras-chave escolhas escolares, ensino secundário, adolescentes, sucesso escolar.

School choices and successful formats in secondary education: paths and timings

The obligation to go to school for an increasingly long period of time has turned schooling into a crucial dimension of biographical construction. In this respect the transition to secondary education is proving to be a particularly critical moment, given that the young person is asked to define a project (for the future) by choosing an educational path. The fact that this occurs during a life stage - adolescence that is characterised by adherence to an exploratory ethic, this projection into the future can lead to tension between biographical rhythms (based on exploration) involved in the construction of the self and institutional calendars (based on the obligation to choose) imposed by the education system. In the present article the authors propose a model for school paths in secondary education that takes account of such tensions.

Keywords school choices, secondary education, teenagers, school success.

Choix scolaires et modalités de réussite dans l'enseignement secondaire: parcours et temporalités

L'obligation d'être scolarisé pendant une période de temps de plus en plus grande a fait de la scolarisation une dimension cruciale de la construction biographique. La transition vers l'enseignement secondaire constitue, sous cet aspect, un moment particulièrement critique dans la mesure où le jeune est invité à définir un projet (d'avenir), en choisissant une filière d'enseignement. Or, comme elle arrive à une 
étape de la vie - l'adolescence - caractérisée par l'adhésion à une éthique d'exploration, cette projection dans l'avenir peut conduire à une tension entre rythmes biographiques (basés sur l'exploration) de construction de soi et calendriers institutionnels (fondés sur l'obligation de choisir) imposés par le système d'enseignement. Cet article propose un modèle de trajectoires scolaires dans l'enseignement secondaire qui tient compte de ces tensions.

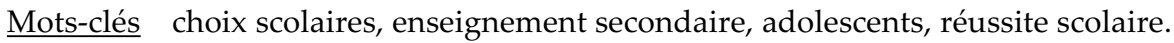

Elecciones escolares y modalidades de éxito en la enseñanza media superior: trayectos y temporalidades

La obligación de frecuentar la escuela, por un periodo de tiempo cada vez mayor, transformó a la escolarización en una dimensión crucial de la construcción biográfica. En este sentido, la transición a enseñanza media superior revela un momento particularmente crítico, una vez que el joven es invitado a definir un proyecto (de futuro), a través de una elección de área escolar. Ahora bien, ocurriendo en una etapa de vida - la adolescencia - caracterizada por la adhesión a una ética de exploración, esta proyección del futuro puede llevar a una tensión entre ritmos biográficos (basados en la exploración) de la construcción de si mismo y calendarios institucionales (basados en la obligación de elegir) impuestos por el sistema de enseñanza. En este artículo, proponemos un modelo de trayectorias escolares en la enseñanza media superior que considera estas tensiones.

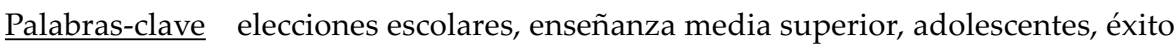
escolar. 